\title{
PRIVATE LETTERS IN OLD INK
}

\author{
Sylvia Townsend Warner
}

(from The Spectator 21st March 1969)

'To make Inke. Four ounces of Gaules Two ounces of green Copperice one ounce and half of Gum Arabick: break the Gaules; the Gum and Copperice must be beaten in a Morter \& put into a quart of white wine or Strong Stale beer (or as others say Smaller beer least it grow to thick) with a little double refined Suger: it should be stood in a Chimney Corner for a fortenight at least $\&$ be well shaken twice or thrice a day the Longer its Kept the Better.'

Chimney corners at Claydon must have held many such bottles. 'There are about 30,000 letters in Claydon House from the seventeenth century,' says Sir Harry Verney in his preface to The Verneys of Claydon (Robert Maxwell 35/-). In the 1860s Parthenope Verney, his step-grandmother, had the enterprise to begin reading them. An enormous task of systematically reading, ordering and transcribing them was continued and carried to completion by her daughter-in-law, Margaret Verney. The resultant four stout volumes have now been abridged by Margaret Verney's octogenarian son into this single volume - a work carried out with filial devotion, albeit with a sense of filial impiety. 'It has been a dreary job murdering my mother,' he wrote to a friend.

Some unrecorded dullard endorsed one bundle 'Private letters of no interest.' The special glory of the Verney hoard is its richness in private letters, letters which cast on public events the revealing illumination of how those events affected contemporary individuals. 'When my mare Lea hath foaled, 
let the foale bee knockt on the head, and the mare taken to Howse, for I cannot spare her this summer.' Lea's foal was a preliminary casualty of the Civil War. A few months after this letter to his steward, Sir Edmund Verney, the King's Standard-bearer, was killed in the battle of Edgehill. Sir Edward Sydenham wrote to Ralph Verney, the heir: 'For all our great vicktorie $I$ have had the greatest loss by the death of your nobell father that ever anie man did ... the battell was bloody on your syde, for your hoorss rann awaye at the first charge, and our men had the execution of them for three miles.' There was no malice in Sydenham's comment on Lord Essex's cavalry. It was a sort of 'Bad luck, old chap.' For the outbreak of the Civil War found both sides inadequately prepared to hate each other, perplexed and socially embarrassed.

Sir Edmund fought for the King but not for the King's cause, which went against his conscience. Sir Ralph was a Parliament man and Member for Aylesbury. A year later, his conscience compelled him to refuse to sign the Covenant. Foreseeing that Claydon would be sequestrated, he did what he could to protect its revenues by leases and trusteeships he had three brothers and five young sisters to think for - and exiled himself to France, taking his personal family and the Vandyke canvases with him. Exile was poverty and fret. 'Noe English maide will bee content with our diet and way of liveing' (Lady Verney's Luce and Besse stayed, for all that). 'There are noe Protestant masters allowed to keepe a schol heere.' 'Let not the wig part behind, charge him to curl it on both sides towards the face.' For in France it was considered clownish to wear one's own hair and Sir Ralph was put to the expense of a periwig and its upkeep.

As a wife is not accountable for her husband's debts and debts, Mary Verney (whose nickname in happier days was Mischief) spent eighteen months in England as Sir Ralph's agent - a double exile, for she loved him - visiting Claydon, where 'Ratts' had gnawed the feather beds, lobbying their London friends to have the sequestration taken off, shopping for the family - not always satisfactorily ('As for Mun's grey stockings they are about a handful too short and almost an 
inch too Little, soe I have laid them upp for your sonn John'), giving birth to a boy child which died - while in France, unknown to her, her young daughter was dying. The sequestration was lifted. She returned to France, to a slow death by consumption. Sir Ralph's day-book of letters received and replied to is interrupted by an outcry of woe. 'Oh my deare deane.' He was thirty-seven, an affectionate fireside man. But in that most remarrying age, he stayed a widower.

He let three more years go by before going back to Claydon. England was a Commonwealth, the battle of Worcester had been fought, bygones were bygones - or best treated as such. Landowning gentry were busy restocking their pillaged woodlands, mending their boundaries. Sir Ralph set a nursery of young fruit-trees, planted firs, limes and walnuts: the latter an act of faith, for walnuts are slowgrowing. He ordered vegetable seeds and vinestocks from France and two thousand Sweet briars for hedging - an example to be commended to the National Trust.

He complied too with Marvell's other prescription: $A$ Stately Frontispice of Poor. The old and destitute had weekly allowances of $3 \mathrm{~d}$ and $6 \mathrm{~d}$, apprentices were portioned, fuel distributed among widows; though the poor were not so rewarding as the plant-kind and frustrated his scheme for improving their cows. Above all, Claydon House had a stately frontispiece of relations. Sisters and their husbands, aunts, nephews and nieces, a spreading cousinry, family friends and their cousinries, turned to him for advice and aid, invited him to stand godfather, relied on him to ease them out of their troubles, find husbands for their daughters, horses for their coaches, told him the latest news from London, urged nostrums on him when he was ill, knew no beer comparable to Claydon beer. 'I live by the strenth of your malt.' They lived by the strength of their confidence in him. ' $I$ have filled the paper,' one letter ends, 'therefore should think of a conclusion, but I fancy myself with you all this time and that is so great a plesur that $I$ forget it is but a fancy.' On one occasion he was asked to spare a wig. 'It 'tis to help away a frind. You shall know all hereafter.' The friend was a young 
cousin of many removes who had taken to highway robbery. Another request was to find a milch ass for Lord Rochester who, repentant and sickly, had been prescribed asses' milk.

In this frontispiece of relations, the figure of Mun Verney (whose grey stockings had been a handful too short) seems to have been portrayed by an artist of a later date, an artist who had studied Watteau's Gilles. Educated in France and something of an intellectual, Mun had married a local heiress and was the squire of East Claydon. He had inherited his mother's sweet temper, but to his undoing. Calamitously matched to a madwoman, bogged clown in debts, flouted by disorderly servants, grown unmanageably fat, to all outward seeming a Sir Tunbelly Clumsy, he accepted his lot with the gentle civility of a superior mind, writing to his tailor, 'My Coate is too scanty in the circumference, a fault a man should not have committed who had ever seen me.' In 1672 he tried to hoist himself out of his squiredom by volunteering to fight the Dutch, and appealed to his father to help him. 'Mun, I pray say noe more of your desire to goe into the Fleet, unless you have a mind to render me \& your children miserable.' Mun subsided: he did not want to render anyone - short of a Dutch admiral - miserable. 'Je choisirai d'ofirir violence à mon genie, et ainsi passer ma vie comme un Faisnéant plus. tôt que comme mu fils desobeissant.' Later he recouped by writing some stern admonishments to his two own sons. They and he all predeceased Sir Ralph. Title and estate went to Mun's brother John, as presumably the stockings had done.

Another family appurtenance passed to Sir John: Tom Verney, the Standard-bearer's second son. Tom's career included three expensively subsidised trips to Barbadoes where it was hoped he might settle (he didn't); a brace of deserted wives; various imprisonments; trailing a pike impartially for either side; a spell on board a warship, where 'noe damned bayliff, nor hellish sergeant can or dare disturb my abode'; a project to become very rich by mining - if Sir Ralph would put up the money; acting as an agent provocateur for Cromwell and possibly as a spy for Charles II; and cultivating every branch of begging letter writing beguiling: "my dayly study now is to serve God and to avoid 
the banquier apprehending mee'; blackmailing: 'Your refusal will caus me to forsake my colours and in so doing I may be liable to a councell of warr, and even be punishable'; lofty: 'Time was, when I have equalized my friends in curtesies, and though I have hitherto been clouded and am brought to a very low ebb, yet their may come a floud of prosperitye, which may inable mee to express my self gratefull. All of us knowes our beginnings, but God knowes our endings. I referer the application to your one sweet self.' Tom's ending did him credit. He lived on in Wales, a family pensioner, till 1707 and died 'merely of old age, his speech and memory perfect to the last.'

Sir Ralph had died eleven years earlier, directing that he should 'be burned as privately and with as little pomp as may be' - a wish unusual at the time but characteristic of the man. He would have been surprised to learn that his unobtrusive steadfastness in well-doing is as real today as it was to the relations - and neighbours who gathered on a tempestuous morning in October 1696 to see him laid in the grave. Surprised; but not, I think, displeased. Other amiable Verneys - in their authenticity of 'private letters of no interest' survive with him. They were his dearest concern. 